\title{
Жариков А.А. \\ Соотношение социально-правовых взглядов российского дореволюционного либерализма и народничества
}

\author{
Северо-Западный институт (филиал) \\ Московского юридического университета имени О.Е. Кутафина (МГЮА)
}

(Россия, Вологда)

doi:10.18411/spc-20-10-2017-01

idsp: 000001:spc-20-10-2017-01

Начало демократического подъема в России, связанного с крестьянской реформой 1861 г. и последующими реформами привело к перегруппировке в сфере господствующих слоев. Консервативному большинству противопоставлялось образованное и оппозиционное меньшинство из числа либералов, именуемых западниками, среди которых были Чичерин Б.Н. и Кавелин К.Д.

Конечные цели либеральной партии были сформулированы в совместном обращении Чичерина и Кавелина в 1856 г. к А.И. Герцену. В нем говорилось: «Мы думаем о том, как бы освободить крестьян без обострения всего общественного организма, мы мечтаем о введении свободы совести в государстве, об отменении или по крайней мере об ослаблении цензуры». Чичерин и Кавелин решительно осуждали приверженность определенной части современников к «революционным и разрушительным планам». Сама перспектива отмены крепостного права на путях мирного обновления воспринималась либералами как надежное средство дать России возможность спокойного развития. В 1859 г. была опубликована статья Кавелина «Взгляд на русскую сельскую общину» и впервые обсуждены в связном виде многие юридические аспекты общинного быта. Кавелин откровенно выступил против превращения общинников в частных собственников земли, чем предвосхитил аргументацию народников конца 60-х и особенно 70-х годов XIX века.

Н.А. Бердяев точно сформулировал народническую парадигму заявив, что в российском сознании XIX века основное место занимала социальная тема, можно даже сказать, что социалистическая тема, осуществление социальной правды и братства людей. Народники надеялись, что Россия избежит капитализма, что она сможет построить лучший социальный строй, миновав капиталистический этап в экономическом развитии. Народники претендовали на то, чтобы быть социалистами в условиях крепостного права и самодержавия.

В основе анархической версии русского народничества - находилась неприязнь к государству, концентрирующему власть в одних руках и порабощающему личность, М.А. Бакунина предлагал «преодолеть государство». В то же время, П.А. Кропоткин признавал полноту и цельность свободы личности и развития всех ее способностей. Это приближает народников к либеральному идеалу, но существенное отличие народников - принципиальное диалектическое соединение общественного и индивидуального.

Примечательно, что выдающиеся либеральные мыслители в России представляли это как определенное логическое противоречие. Особенно заметно различие либеральной и народнической концепции гуманистической мысли на примере работы П.И. Новгородцева «Об общественном идеале». Новгородцев, оппонируя анархистам, указывает, что в обществе свобода человека всегда ограничивается, и соединение высшей свободы личности с гармонией общения так же исключено, как смешение белого и черного без всякого для них ущерба.

Социально-правовой идеал народничества ориентирован на будущее, в котором нет разделения личности и общества, связан с представлением о прогрессе социальных 
отношений и развитием личности. Народники видели особый путь России, которая должна была стать основой для преобразования всего человечества и построения совершенного общества по законам справедливости, братства, гуманизма и уважения личности.

Либеральная и народническая социально-правовые концепции по-своему ограниченны. Либерализм нерешителен там, где общество созрело для преобразований. Народничество, таит в себе опасность активных, насильственных действий там, где общество еще не готово для каких-либо решительных перемен. Российское народничество признавало неизбежность социальной революции в России и необходимость готовиться к ней. Российский либерализм упустил момент возможного мирного разрешения социальных задач, и тем самым открыл дорогу народничеству, отвергшему казалось бы, вполне разумные и взвешенные альтернативы «государственного либерализма».

Малейшее сотрудничество с властью со стороны представителей интеллигенции превращало их в политических изгоев. Это подтверждает реакция «образованного общества» на выход сборника «Вехи» в котором делалась попытка «семи смиренных» содействовать власти перед угрозой надвигающейся народной революции.

Видимо, у России в начале XX века была единственная возможность избежать ужасов гражданской войны: уже после первой русской революции либералам следовало начать жестко и последовательно развивать конституционную монархию с перспективами республиканского строя. Однако веховцы раскололи российскую интеллигенцию, «проявили слабость» и позволили восторжествовать реакции.

Либеральный ученый-юрист П.И. Новгородцев отмечал, что политико-правовое сознание русской интеллигенции сложилось не под влиянием либерального консерватизма Б.Н. Чичерина, но под влиянием народнического анархизма М.А. Бакунина. Решающим началом стало не уважение к историческим задачам власти и государства, а уверенность в силе революции и в сознании народных масс. Дух народничества был повсюду, внедряясь во все сферы жизни российского общества. Это вызывало неизбежную радикализацию взглядов носителей «народной правды». Как верно пишет П.И. Новгородцев, народ, вступив на революционный путь, на путь проявления своей воли, неизбежно должен был докатиться до большевизма.

В состоянии полной социальной разобщенности элиты и народа, постепенно возникает вопрос их диалога, это особенно актуально в условиях формирования буржуазных отношений и поиска объединяющего начала. Народническая социальноправовая парадигма это способ консолидации нации для снятия сословных различий и создания единого правового пространства для всех представителей общества, в России он приобрел самобытный всеохватывающий характер. Это обусловлено жестким противодействием властей сокращению социально-правовой дистанции между господствующими слоями и народом.

$$
* * *
$$

1. Графский В.Г. Политические и правовые взгляды русских народников (истоки и эволюция). - М.: Наука, 1993. - 319 с.

2. Чичерин Б.Н. Избранные труды / Подготовка текста, составление, вступительная статья и комментарии А.В. Полякова. - СПб.: Изд-во С.-Петербургского ун-та, 1997. - 555 с.

3. П.И. Новгородщев. Об общественном идеале. - М.: УРСС, 1991. - 640 с.

4. Фролова Е.А. Методология и философия права: от Декарта до русских неокантианцев: монография. - М.: Проспект, 2017. - 304 с.

5. Вехи. Сборник статей о русской революции. Репринтное издание. - М.: Новости, 1990. -216 с. 